\title{
Nurse management of ischemic thoracic pain in hospital emergency services
}

\begin{abstract}
Chest pain is sometimes the reflection of minor pathologies, but in others, it is the expression of serious situations. The most important aspect in patients with chest pain is to detect the presence of Acute Coronary Syndrome since $20 \%$ of the consultations of the hospital emergency services for chest pain are diagnosed with acute myocardial infarction. The general objective is to evaluate the scientific evidence on interventions and treatment in patients with ischemic chest pain in the emergency services. The bibliographic search was carried out in the period of time between November 2019 and May 2020, finally a total of 24 articles were selected. The results show that DT caused by SCA can be treated pharmacologically with the new P2Y12 inhibitors, although it is not recommended that the treatment be exclusively pharmacological. The optimal time to initiate other treatment strategies such as coronography and coronary intervention is 12 to 24 hours.
\end{abstract}

Volume 6 Issue 2 - 202I

\author{
Astasio Picado Álvaro \\ PhD, Nursing and Physiotherapy Department, University of \\ Castilla-La Mancha, Spain
}

Correspondence: Álvaro Astasio Picado, PhD, Nursing and Physiotherapy Department, University of Castilla-La Mancha, Spain, Email alvaro.astasio@gmail.com

Received: March 03, 2021 | Published: March 19, 202

Keywords: chest pain, acute coronary syndrome, nursing care, ischemic heart disease, unstable angina pectoris

\section{Introduction}

Chest pain (CP) is sometimes the reflection of mild pathologies, but in others, it is the expression of extremely serious clinical situations. This symptom has defining characteristics that help diagnose it, but performing this work in the emergency services is part of a very common challenge faced by healthcare professionals, this is because the etiology of chest pain is very diverse. For this reason, it becomes a great burden on healthcare. ${ }^{1}$

$\mathrm{CP}$ is defined as "a localized high sensation in the area between the diaphragm and the supraclavicular fossa". ${ }^{2}$

Consultations for CP are very frequent, in Spain, it is estimated that between $5 \%$ and $10 \%$ of HUS consultations are for non-traumatic DT. ${ }^{2}$

Table I Characteristics of ischemic DT
DT is the main clinical manifestation of Acute Coronary Syndrome (ACS). However, the presence of DT is not as frequent in the older adult. According to the North American National Registry of Myocardial Infarction, chest pain occurs in $77 \%$ of patients younger than 65 years, while in the population between 65 and 75 years it occurs in $50 \%$ of cases, and It only occurs in $40 \%$ of adults over 85 years of age. ${ }^{3}$

With the aim of improving the quality of healthcare in these patients, in recent years, the creation of chest pain units (UDT) has been launched to centralize healthcare. ${ }^{4}$

\section{Characteristics of chest pain of ischemic origin}

The clinical pattern of DT of ischemic origin includes two clinical situations; angina and AMI, and has the following characteristics (Table 1).

$$
\begin{aligned}
& \text { Location } 1,2,12 \\
& \text { Chest center, retrosternal. It can be seen in another area from the epigastrium to the neck, interscapular area, jaw, } \\
& \text { shoulders, arms, wrists and fingers. It is perceived as oppressive, strong, constrictive, or fiery. }
\end{aligned}
$$

Before the arrival of a patient with DT, to the emergency department, two clinical situations can be observed:

- Patient with DT and hemodynamic changes: pain accompanied by changes in BP, dyspnea, arrhythmias, decreased level of consciousness or shock.

- Patient with DT without hemodynamic changes: the pain is not accompanied by cardiac changes or in the BP figures, nor by vegetative symptoms.

Assessing the patient's hemodynamics provides important data that helps detect and differentiate those causes that can cause a risk to the patient's life. For this reason, DT is classified according to its origin. ${ }^{5}$

The correct diagnosis and treatment of DT is a great difficulty in healthcare, since $2-10 \%$ of patients who go to HEDs for this reason are discharged with a wrong diagnosis, the consequence of this failure increases mortality rate. ${ }^{6}$

\section{Chest pain assessment}

It is essential to collect information on the following aspects (Table 2): ${ }^{5,7}$ 
Table 2 Clinical examination of the patient with DT

\begin{tabular}{ll}
\hline Personal history & $\begin{array}{l}\text { Determine the } \\
\text { characteristics of pain }\end{array}$ \\
\hline $\begin{array}{l}\text { Age, sex. } \\
\text { Presence of CVRF. }\end{array}$ & $\begin{array}{l}\text { Start. } \\
\text { Duration. }\end{array}$ \\
History of cardiovascular pathology. & Location. \\
$\begin{array}{l}\text { Family history of premature coronary } \\
\text { heart disease. }\end{array}$ & Triggers. \\
$\begin{array}{l}\text { History of infection. } \\
\text { History of immobilization, if so, } \\
\text { suspect the presence of pulmonary } \\
\text { thromboembolism. }\end{array}$ & Factors that relieve pain. \\
\hline
\end{tabular}

\section{Cardiovascular risk factors (CVRF)}

Cardiovascular diseases (CVD) are the main cause of premature death and disability worldwide, specifically in developed countries, causing high costs in the healthcare system. ${ }^{8}$

In 2016, in Spain, diseases of the circulatory system were the leading cause of death, especially ischemic heart disease was responsible for the majority of deaths. ${ }^{9,10}$

The etiology of CVD depends on multiple factors, including cardiovascular risk factors (CVRF). CVRFs can be classified into three groups; causal, predisposing and conditioning. ${ }^{4,10,11}$

The main most prevalent CVRFs are: ${ }^{12-14}$

Diabetes.

Dyslipidemia.

HTA.

Obesity.

Smoking.

Alcoholism

\section{Acute coronary syndrome (ACS)}

Acute Coronary Syndrome constitutes a set of ischemic states of the heart. It is classified into 3 groups using the ST segment elevation or not, visible on the ECG. ${ }^{1,2,15}$

Cardiomyocyte necrosis is called Acute Myocardial Infarction (AMI) in a clinical setting compatible with acute myocardial ischemia. $^{12,16}$

During recent years, the incidence of AMI in Castilla-La Mancha is 130 cases per 100,000 inhabitants, and in this autonomous community, AMI is the leading cause of death in women and the second in men. ${ }^{17}$

To make the correct diagnosis of ACS, a first evaluation of the patient with DT must be carried out, which includes the following sections: ${ }^{2}$

The clinical manifestations of myocardial ischemia include: ${ }^{1,16}$

DT.

Dyspnoea.

Pain in upper limbs, discomfort in the jaw or in the epigastrium.

Diaphoresis, syncope or fatigue.

The clinical history of the patient with suspected ACS is important for the correct diagnosis and treatment. For this reason, the history of coronary heart disease, sex, age, and presence of CVRF associated with ACS should be evaluated. ${ }^{1}$

Elevated levels of cardiac troponin (I or T), or creatinine kinase MB fraction (CKMB), indicate that there is necrosis in myocardial cells. Necrosis of the heart muscle begins to develop 15-30 minutes after complete occlusion of the artery. ${ }^{1,3}$

Troponin I or $\mathrm{T}$ is the cardiac biomarker par excellence due to its sensitivity and specificity indicative of myocardial necrosis. They appear altered in blood between 1-3 hours after the onset of symptoms, and reach their maximum values at $12-48$ hours, remaining elevated after $7-10$ days. ${ }^{1,2,13}$

CKMB is used when other types of biomarkers are not available. It is not recommended to use it for routine diagnosis, since this value rises after 4-8 hours after AMI, and normalizes two or three days later. ${ }^{1,13}$

The result of the figures for these biomarkers cannot be used as a single result to determine the diagnosis of AMI. ${ }^{1,2,16,17}$

The 12-lead electrocardiogram is the first test that must be performed on every patient who comes to the ED for DT for the first 10 minutes. ECG values and interpretation lead to four possible diagnoses: SCACEST, SCASEST, confusing ECG, normal or nonspecific ECG. ${ }^{2,12}$

Nitroglycerin is a vasodilator drug, so it is only administered in patients with DT of ischemic origin. Administration is indicated when the patient has a TAS $>90 \mathrm{mmHg}$ or TAD $>100 \mathrm{mmHg}$. However, it should not be used if the HR is $<50 \mathrm{bpm}$ or $>100 \mathrm{bpm}$. Its administration should be discontinued when symptoms have subsided. ${ }^{13-15}$ Start with an ASA dose of 150-300 mg. If there are any contraindications to administering ASA, Clopidogrel is used as an alternative..$^{8,14,18}$

The second antiplatelet drug must be a P2Y12 inhibitor, since they have greater potency and better results, making them the drugs of first choice. If there are any contraindications to the administration of these, Clopidogrel is used instead. ${ }^{8,14}$

Coronary reperfusion therapy is the basis for the treatment of ACS, specifically for SCACEST, since it is a time-dependent disease whose prognosis largely depends on initial management. ${ }^{19}$ Coronary reperfusion includes two strategies; pharmacological thrombolysis and percutaneous coronary intervention. ${ }^{19-21}$

\section{Risk prediction scales}

The Global Registry of Acute Coronary Events (GRACE) scale was developed to predict the prognosis and CVRF associated with patients after ACS, and also assesses the prognosis of death one month and 6 months after discharge from hospital. ${ }^{3,22-24}$ Another TIMI (Trombolysis in Myocardial Infarction) scoring system developed with the aim of predicting 30-day and one-year mortality after SCACEST. In addition, this scale presents the ability to make a global estimate of the risk presented by this type of patient. ${ }^{3,25-27}$ The Heart Score scale was developed to make decisions about those patients who come to the ED with related symptoms or symptoms. with ischemic heart disease. This scale identifies patients with a low risk of major cardiac events. For this reason, it allows evaluating these patients without the need for explorations or tests that do not really require. ${ }^{28,29}$

\section{Material and methods}

The elaboration of this work was carried out through a bibliographic search in scientific databases between the month of November 2019 and May 2020, in order to carry out a narrative review of the literature. 
For the selection of the scientific articles on which this narrative review is based, the following criteria have been carried out:

\section{Inclusion criteria:}

Year of publication: from 2015 (inclusive), until May 2020.

Free access.

Text complete.

Languages: Spanish and English.

Publications in scientific databases.

Exclusion criteria:

Articles published prior to 2015 .

Items whose access was by payment.

Those articles that only the introduction was visible.

Articles that are not published in scientific databases.

Articles written in languages other than Spanish and English.

The studies will be identified by means of computerized searches in bibliographic databases and in reference lists of articles. The selected sources of information were in the language of English, French and Spanish. The following databases were used: Pubmed (2014-2019), Scopus (2014-2019), Wos (2014-2019), Google Scholar (2014-2019). The first search was carried out on November 12, 2019 and ended on
May 10, 2020. In addition to searching databases, the list of article references was verified, and the information obtained through the analysis of trial registries, protocols and institutional websites.

In November 2019, the electronic bibliographic databases of Pubmed, Scopus, Wos, Google Scholar were consulted to locate articles published from 2015 inclusive to 2020. The language of the studies was limited to English / French / Spanish. Keywords such as "chest pain", "acute coronary syndrome", "nursing care", "ischemic heart disease", "unstable angina pectoris" were used in the search strategy. Reference lists of included studies were checked to select the most complete ones.

Finally, for this review, a total of 24 articles have been selected. Of all of them, 1 has been published in a journal with level of evidence Q1 and 11 of level of evidence Q2. The rest of the articles have been published in different magazines that do not appear on the Web of Sciencie (WOS), so they do not have a Journal Citation Reports (JCR).

To carry out the selection of these studies, a first bibliographic search was carried out, from which 210 articles were obtained. After applying the inclusion and exclusion criteria, as well as eliminating duplicate and irrelevant articles both by their abstract and by their title, 24 articles were selected for this review.

\section{Results}

Below is a Table 3 that shows the search strategy used to select the articles:

Table 3 Databases consulted

\begin{tabular}{lllllll}
\hline & $\begin{array}{l}\text { PUBMED/ } \\
\text { MEDLINE }\end{array}$ & $\begin{array}{l}\text { ELSEVIER/ } \\
\text { EMBASE }\end{array}$ & SCIENCE & DIALNET & $\begin{array}{l}\text { GOOGLE } \\
\text { ACADÉMICO }\end{array}$ & TOTAL \\
\hline Selected & 55 & 54 & 23 & 35 & 43 & 210 \\
Duplicates & 5 & 4 & 2 & 5 & 3 & 19 \\
Payment Access & 10 & 21 & 7 & 5 & 6 & 49 \\
Title Only & 20 & 18 & 4 & 9 & 13 & 64 \\
Summary Only & 11 & 7 & 5 & 8 & 13 & 44 \\
Text Complete & 2 & 1 & 2 & 1 & 4 & 10 \\
Valid & 7 & 3 & 3 & 7 & 4 & 24 \\
\hline
\end{tabular}

To carry out the narrative review, 24 articles were used to assess the management of ischemic chest pain in hospital emergency services.

\section{Discussion}

In relation to the risk prediction scales, the most studied are GRACE, TIMI and HEART. Being TIMI and GRACE the most used worldwide for risk assessment, they are also a very useful tool to identify risk situations. ${ }^{30,31}$

According to the authors Pérez Corral A.M. et al, the most widely used scale in HEDs that serve a large number of people is TIMI. It is also used in predicting the risk of death in patients who have undergone STEMI. ${ }^{23,32}$

The GRACE scale uses the prediction of hospital death after an AMI. The authors Santos Medina M. et al confirm the validity of this scale in their study, which shows that hospital mortality was $51.8 \%$ in patients who were at high risk on this scale. However, it is not useful to rule out an SCA. ${ }^{24}$
GRACE is better able to predict events at one month, while TIMI is better able to predict events at six months. In contrast, these two scales are not useful for diagnosing ACS in patients with an ECG and negative Troponins, despite their high risk. ${ }^{30,32}$

The HEART scale has greater discriminatory capacity when used in undifferentiated DT, according to the authors Pérez Corral A.M et al. It is more useful for the prognosis of cardiovascular events, compared to the two previous scales. ${ }^{26,33}$

Patients who come to the HED for DT and who also have a low risk according to the HEART scale, have little probability of developing coronary events in the following 30 days, so they can be discharged from the HUS, this information is supported by the authors Chan AM et al in their study. ${ }^{34,35}$

With regard to the characteristics of DT, it manifests itself most sharply, and less oppressively. The evolution is over 12 hours and is not usually accompanied by vegetative symptoms. However, in elderly people, ACS manifests itself through atypical DT associated 
with the presence of fatigue, dizziness and dyspnea, in addition, the latter increases the probability of suffering an ACS. ${ }^{15,36,37}$

According to the authors, Domínguez Rodriguez A et al affirm that the physician, sometimes, does not pay attention to 9 important variables that are obtained in the initial evaluation of the patient, since these can lead to the diagnosis of ACS, and are the following: DT of oppressive, retrosternal, epigastric character, irradiated to the shoulders, the precipitating factor of which is a situation of exertion, pain associated with vegetative symptoms and the presence of dyspnea, the duration is between 5-20 minutes of repetition during the last 24 hours. ${ }^{37}$

In relation to diagnostic tests for DT in HEDs, clinical guidelines recommend performing an ECG, determination of highly sensitive troponins, and cardiovascular risk stratification. ECG and troponins continue to be the two priority tests in patients with DT. Troponin elevation is used as an element in the classification of patients at high risk. There are two other elements that provide important data such as the patient's medical history and physical examination. There is a clear relationship between the data obtained in the patient's interview and the objective changes in the ECG with the final and initial diagnosis of ACS. ${ }^{35,38-40}$

The ECG in the elderly patient usually provides nonspecific data, it is common to observe ST segment elevation and left bundle branch block, for this reason, it is advisable to compare the new ECG with old ones if they are available. ${ }^{36}$

The presence or not of DT together with the elevation of the troponins has various diagnostic implications; according to the authors González del Hoyo M. et al the absence of DT together with the elevation of troponins is more frequent in elderly patients, this in turn, is related to a decrease in the performance of complementary tests, an increase in mortality, worse prognosis and less diagnosis of ACS. The diagnosis of ACS is more frequent in those patients who do present DT with troponin elevation..$^{40,41}$

The study carried out by Alfonso F. et al states that the determination of troponins together with the performance of a computed tomography jointly form a more accurate and faster diagnostic strategy for ACS. ${ }^{42}$

The ACEP recommends using 3 diagnostic elements in those patients who are at risk of suffering major cardiovascular events: determination of the HEART, TIMI scales and troponin seriation, to avoid subjecting patients at low risk to the ischemia provocation test. ${ }^{39}$

After the evaluation of a heart attack code in the study by Cordero A et al, it was concluded that the hospital stay was shorter after the implantation of said code, with no variation in the mortality rate. The treatment of choice was angioplasty. ${ }^{19}$

In relation to the treatment of SCASEST, the authors Bueno $\mathrm{H}$ et al affirm that mortality is higher in patients with exclusively pharmacological treatment, associated with older patients. With respect to the drugs used in the treatment of ACS, P2Y12 inhibitors have lower scores on the GRACE and CRUSADE scales, but they are less used if the risk of bleeding or ischemia is high on these scales, which is why a increased use of these drugs when there is less risk. Advanced age is the only factor on the GRACE scale that is associated with decreased use of these drugs. These drugs reduce mortality and thrombotic events without increasing bleeding as Clopidogrel does. ${ }^{27,37,43,44}$

Regarding the optimal time to start coronary revascularization therapy is between 12-24 hours, since greater complications are observed in those patients in whom treatment is started late. The performance of the treatment in this period of time is related to an increase in survival. ${ }^{45,46-54}$

\section{Conclusion}

Chest pain caused by ACS can be treated pharmacologically with the new P2Y12 inhibitors, as they have been shown to reduce mortality and thrombotic events. It is not recommended that the treatment be exclusively pharmacological since mortality is higher. The appropriate time to start other treatment strategies such as coronography and coronary intervention is $12-24$ hours. The guidelines recommend the performance of the ECG, together with the determination of troponins and the stratification of the CVR, without forgetting to pay attention to the patient's medical history and physical examination. In relation to the characteristics of the pain that is caused by ACS, it presents stabbingly, the evolution is longer than 12 hours and is not normally accompanied by vegetative symptoms, however, in elderly patients, DT is atypical and It is associated with fatigue, dizziness, and dyspnea. The TIMI and GRACE scales are the most widely used globally for risk assessment. The best scale that can be used in those HEDs that serve a high volume of patients is TIMI, in addition, this scale better predicts events at 6 months, and GRACE does it at one month. The HEART scale has greater discriminatory power in a patient with undifferentiated type DT.

\section{Acknowledgments}

None.

\section{Conflicts of interest}

The authors declare that there is no conflict of interest.

\section{References}

1. Díaz Castro O. Coordinador. Síndrome coronario agudo sin elevación del ST (SCASEST). Estándar de Calidad SEC; 2017.

2. https://docplayer.es/4797439-Dolor-toracico-m-v-hidalgo-sanjuan-m-cfernandez-aguirre-f-linde-de-luna-r-rodriguez-martinez.html

3. Llancaqueo M. Manejo del síndrome coronario agudo en el paciente adulto mayor. Revista Médica Clínica Las Condes. . 2017; 28(2):291-300.

4. Miró O, Martínez Nadal G, Jiménez S, et al. Asociación entre los datos clínicos y electrocardiográficos iniciales en pacientes con dolor torácico no traumático y la sospecha inicial y el diagnóstico final de síndrome coronario agudo. Emergencias [internet]. 2020;32:9-18.

5. Luna Aljama J, Serrano Carmona JL. Actuación de enfermería ante el dolor torácico en urgencias. Revista Portales Médicos. [internet]. 2015.

6. Castellanos Rodríguez A, Obaya Rebollar JC, Bueno $\mathrm{H}$, et al. coordinadores. Procesos asistenciales compartidos entre atención primaria y cardiología. 2015;7-13.

7. Reyes Sanamé FA, Pérez Álvarez ML, Alfonso Figueredo E, et al. Reyes Sanamé Félix Andrés, Pérez Álvarez María Luisa, Alfonso Figueredo Ernesto, Céspedes Cuenca Yoslainy, Fernández Mendoza Alianna. El método clínico aplicado al diagnóstico del dolor torácico agudo. Revista Panamericana de Salud Pública [internet]. 2018; 22(3):474-495.

8. Millá Perseguer M, Guadalajara Olmeda N, Vivas Consuelo D. Impacto de los factores de riesgo cardiovascular en el consumo de recursos en Atención Primaria según los grupos de riesgo clínico. Atención Primaria. 2017;51(4):218-229.

9. https://www.ine.es/prodyser/espa_cifras/2018/21/\#zoom $=\mathrm{Z}$

10. Ramírez Iñiguez de la Torre MV, Vicente Herrero MT, López González AA, et al. Factores de riesgo cardiovascular y su relación con factores sociodemográficos y laborales en trabajadores aparentemente sanos. Rev Asoc Esp Espec Med Trab [internet]. 2017; 26(4):257-265. 
11. Fontana Talens E, Pérez Soriano AA, Perez Molto FJ. Factores de riesgo de las enfermedades cardiovasculares. Cardiopatía isquémica. Majorensis [revista en internet]. 2019;15:14-23.

12. Jiménez M, Mata A. Dolor torácico. Guías de actuación en urgencias. Clínica Universidad de Navara; 2018.

13. Duronto E, Navarro Estrada JL. Consenso para el manejo de pacientes con dolor precordial. Revista Argentina de Cardiología [internet]. 2016;84 (4):378-401

14. https://www.urgenciasyemergen.com/wp-content/uploads/dlm uploads/2018/10/Manual-de-urgencias-3ed-Bibiano.pdf

15. López Barbeito B, Martínez Nadal G, Bragulat E, et al. Evolución de las características de las visitas por dolor torácico no traumático en una unidad de dolor torácico durante un periodo de 10 años (2008-2017). Emergencias [internet]. 2019;31:377-384.

16. Alfonso F, Salamanca J, Pozo E. Diagnóstico de síndrome coronario agudo en pacientes con dolor torácico en urgencias: ¿cambios a la vista? Emergencias [internet]. 2016;28:6-8.

17. Llanos Val Jiménez C, Del Campo Giménez M, García Atienza EM. Actualización del código de reperfusión coronaria de castilla- la mancha (CORECAM). medidas de actuación en atención primaria. Rev Clin Med Fam [internet]. 2019;12(2):75-81.

18. Domínguez-Moreno R, Bahena-López E, Neach-De la Vega D, et al Abordaje del dolor torácico. Medicina Interna de México. 2016;32(4):461474.

19. Cordero A, López Palop R, Carrillo P, et al. Cambios en el tratamiento y el pronóstico del síndrome coronario agudo con la implantación del código infarto en un hospital con unidad de hemodinámica. Revista Española de Cardiología [internet]. 2016; 69(8):754-759.

20. Borda Velásquez L, Razzeto Rubio L, Rey Mendoza J, et al. Estrategias de reperfusión usadas en pacientes con síndrome coronario agudo con elevación persistente del segmento ST en un hospital general. Rev Med Hered [revista en internet]. 2015;26:35-41.

21. Olivera Escalona AL. Reperfusión coronaria en el infarto agudo de miocardio con elevación del segmento ST: importancia del contexto y tiempo de aplicación. Medisan [revista en internet]. 2015;19(10):12591267.

22. http://www.samiuc.es/modelos-pronosticos-grace-mortalidad-losprimeros-6-meses-tras-alta/

23. Sénior JM, Fernández A, Rodríguez A, et al.. Validación y comparación de los puntajes TIMI y GRACE en pacientes con síndrome coronario agudo sin elevación del segmento ST. Revista Colombiana de Cardiología [internet]. 2016;23(6):479-486.

24. Santos Medina M, Valera Sales A, Ojeda Riquenes Y, et al. Validación del score GRACE como predictor de riesgo tras un infarto agudo de miocardio. Revista Cubana de Cardiología y Cirugía Cardiovascular [internet]. 2015;21(2).

25. Betancourt-Plaza I, Martos-Benítez FD. Escala TIMI como predictor de muerte en pacientes con infarto miocárdico agudo sin intervención coronaria percutánea. CorSalud [internet].2016;8(2):111-116.

26. http://www.samiuc.es/timi-risk-score-scasest/

27. Ugalde H, Cecilia YM, Sebastián R, et al. Validación del puntaje del riesgo TIMI como predictor de mortalidad en pacientes chilenos con infarto agudo al miocardio con supradesnivel de ST. Rev med Chile [internet]. 2017;145(5): 572-578

28. Cortés M, Lambardi F, Ariznavarreta P, et al. Utilidad del score HEART con troponina $\mathrm{T}$ de alta sensibilidad para la evaluación de pacientes con dolor torácico. Revista Argentina de Cardiología [internet]. 2018;86(5):333-337.
29. Mark DG, Huang J, Chettipally U, et al. Rendimiento de las puntuaciones de riesgo coronario entre pacientes con dolor torácico en el servicio de urgencias. Revista del Colegio Americano de Cardiología [internet]. 2018;71(6):606-616.

30. Pérez Corral M, Benito Ruiz E, Fernández Rodrigo MT, et al Estratificación del riesgo en el dolor torácico en urgencias. Revisión sistemática. Nure inv [internet]. 2017; 15(92):1-11.

31. Sprockel Díaz J, González Russi M.L, Barón R. Escalas de riesgo en el diagnóstico de la angina inestable en pacientes con dolor torácico con electrocardiograma y biomarcadores negativos. Repertorio de Medicina y Cirugía [internet]. 2016; 25(3):256-162.

32. Sprockel Díaz JJ, Mantilla Durán HJ, Cruz Daza LC, et al. Aplicación de las escalas de estratificación del riesgo en el diagnóstico de los síndromes coronarios agudos. Revista Colombiana de Cardiología [internet]. 2017;24(5):480-487.

33. Chacón Díaz M, Salinas J, Doig R. Estratificación con el score HEART modificado y su relación con eventos adversos cardiovasculares a corto plazo. Archivos de Cardiología de México [internet]. 2017; 88(5):333338.

34. Betancourt Plaza L, Martos Benítez D. Escala TIMI como predictor de muerte en pacientes con infarto miocárdico agudo sin intervención coronaria percutánea. Cor Salud [internet]. 2016; 8 (2):111-116.

35. Chang AM, Holander JE. Dolor torácico: ¿ temerlo o abordarlo con sensatez?. Emergencias [internet]. 2020;32:7-8.

36. Pineda Isaza A, Sánchez Cano F.M. Síndrome coronario agudo en el anciano: evaluación, diagnóstico y tratamiento. Archivos de medicina [internet]. 2017;17(1):131-141.

37. Domínguez Rodríguez A, Hernández Vaquero D. Síndrome coronario agudo: un diagnóstico siempre difícil en urgencias- regla del 9-. Emergencias [internet]. 2020; 32:-4.

38. Miró O, Martínez Nadal G, Jiménez S, et al. Asociación entre los datos clínicos y electrocardiográficos iniciales en pacientes con dolor torácico no traumático y la sospecha inicial y el diagnóstico final e síndrome coronario agudo. Emergencias [internet]. 2020;32:9-18.

39. Povar Marco J. La organización de la atención al dolor torácico en urgencias. Emergencias [revista en internet]. 2019;31(6): 371-372.

40. Biener M, Mueller M, Vafaie M, et a. Impacto de los principales síntomas de presentación en el rendimiento diagnóstico de la troponina T cardíaca de alta sensibilidad y en los resultados en pacientes con sospecha de síndrome coronario agudo. Clinical Chemistry [internet]. 2015;61(5):744-751.

41. González del Hoyo M, Cediel G, Carrasqur A, et al. Implicaciones diagnósticas y en el pronóstico de la elevación de troponina en ausencia de dolor torácico en pacientes atendidos en urgencias. Emergencias [internet]. 2018;30:77-83.

42. Almendro Delia M, García Alcántara A, de la Torre Prados MV, et al. Seguridad y eficacia clínica con prasugrel y ticagrelor en síndrome coronario agudo. Resultados de un registro multicéntrico en el mundo real. Revista Española de Cardiología [internet]. 2017; 70(11):952-959.

43. Bueno $\mathrm{H}$, Pocock $\mathrm{S}$, Medina J, et al. Relación entre las situaciones clínicas que llevan al tratamiento exclusivamente farmacológico del SCASEST y su pronóstico. Revista Española de Cardiología [internet]. 2017;70(10):817-824.

44. Flores Blanco PJ, Cambronero Sánchez F, Raposeiras Roubin S, et al. Asociación entre las escalas de riesgo isquémico y hemorrágico y el uso de los nuevos inhibidores $\mathrm{P}_{2} \mathrm{Y}_{12}$ en pacientes con síndrome coronario agudo. Rev Esp Cardiol. 2018;71(7):538-544.

45. Carballoso García L, Carballoso García VJ, Orea Cordero I, et al. Estrategia invasiva, inmediata, mediata y tardía en el síndrome coronario agudo sin elevación del segmento ST. Cor Salud [internet]. 2018;10(3):192-201. 
46. Ibanez B, James S, Agewall S, et al. ESC Guidelines for the management of acute myocardial infarction in patients presenting with ST-segment elevation: The Task Force for the management of acute myocardial infarction in patients presenting with ST-segment elevation of the European Society of Cardiology (ESC). European Heart Journal [internet]. 2018;39(2):119-177.

47. Reyes Sanamé FA, Pérez Álvarez ML, Alfonso Figueredo E, et al. Clinical application of acute thoracic pain diagnosis. [internet]. Correo Cientifico Médico. 2018; 22(3):474-495.

48. Martín DM. Proceso asistencial simplificado del síndrome coronario agudo. 2017: 151.

49. Rubio Sevilla JC. Actuación de enfermería ante una alteración electrocardiográfica ( $6^{\mathrm{a}}$ parte) Onda Q, segmento ST y onda T. Síndrome coronario agudo. Enfermería en Cardiología [internet]. 2016;23(68):30 36
50. Martín Sánchez FJ, del Toro Daza E, Llorens P, et al. Validación de la escala HEART en los pacientes con dolor torácico atendidos en los servicios de urgencias. Emergencias [internet]. 2019; 31:209-217.

51. Carlton E.W, Than M, Cullen L, et al. Chest Pain Typicality" in suspected acute coronary syndromes and the impact of clinical experience. The American Journal of Medicine [internet]. 2015;128(10):1110-1116.

52. https://medlineplus.gov/spanish/ency/article/000195.htm

53. https://vsearch.nlm.nih.gov/vivisimo/cgi-bin/query-meta?v\%3afile=viv 
a9r\&server=pvlbsrch $13 \& \mathrm{v} \% 3$ astate=root $\% 7$ croot\&url=https $\% 3 \mathrm{a} \% 2 \mathrm{f} \% 2 \mathrm{fmedlineplus.gov} \% 2 \mathrm{fspanish} \% 2 \mathrm{fency} \% 2 \mathrm{farticle} \% 2 \mathrm{f} 000201 . \mathrm{htm} \& \mathrm{rid}=\mathrm{Ndoc} 0 \& \mathrm{v}$ $\% 3$ aframe $=$ redirect $\& \mathrm{v} \% 3$ aredirect-hash $=6105280 \mathrm{~b} 174278 \mathrm{bd} 3 \mathrm{e} 5 \mathrm{e} 42 \mathrm{~d} 0 \mathrm{eacde} 97 \mathrm{e} \&$

54. http://revista.asomigua.org/2017/01/28/rifarsse-para-leer-electrocardiogramas-apropiadamente/ 